\title{
The Word gid in Najdi Arabic: An Evidentiality Head
}

\begin{tabular}{l|ll}
\hline Correspondence: & $\begin{array}{l}\text { Ahmad Radi Alshammari } \\
<\text { am.alshammari@uoh.edu.sa }> \\
\text { Wafi Fhaid Alshammari } \\
\text { <wf.alshammari@uoh.edu.sa }>\end{array}$ & Assistant Professor, University of Ha'il, Kingdom of Saudi Arabia \\
\hline
\end{tabular}

Abstract

This research paper investigates the word gid which is used in Najdi Arabic, a dialect spoken in Najd region in Arabic peninsula. This particle is analyzed syntactically using the recent assumptions of the minimalist program (Chomsky, 1993, 1995, and subsequent work). As for the findings, it turns out that gid functions as a head that instantiates its maximal projection above TP and under CP. So, this word is not a property of TP domain nor a CP domain. Due to the fact that this word is only used when a speaker is certain of the propositional content of his/her utterance, we argue that gid is an evidential head that scopes over the tense layer. Furthermore, we argue that gid has an EPP feature, hence the specifier position of the functional phases headed by it must be filled by some element which is the subject. This accounts for the fact that subject must precede gid in declarative sentences. Additionally, gid has [PAST] feature which is uninterpretable and hence must be deleted before the derivation is handed over to the LF following the general lines of feature deletion of Chomsky (1995, 2005). We argue that the deletion of [PAST] feature is conducted through an Agree operation that is established between gid and the verb. This is why gid comes exclusively with past tense. Otherwise [PAST] feature on gid remains active, leading to the ungrammaticality of the given sentence.

Keywords: Evidentiality, the EPP feature, agree operation, TP, probing

\section{Introduction ${ }^{1}$}

Investigating grammaticality of words and their syntactic functions is for long considered as one of the main destinations of both synchronic and diachronic syntax (Brinton, 1996, Hopper \& Traugott, 2003, Trousdale, 2008, Thepkanjana \& Ruangmanee, 2015). The importance of such studies lies in the assumption that grammaticalized words and their syntactic functions bring to us reliable clues of how languages are developing and how syntactic functions are carried out and represented in discourse (Hopper \& Traugott, 2003, DeLancey, 2004, \& Heine, 2006, among many others). Accordingly, grammaticalized words are significant clues of language processing as well as evolution. One such is expressing evidential through grammaticalized items. What this basically means is that when a speaker uses these constructions or grammatical items, he/she is evident that the propositional content of the utterance is right for the best of his/her knowledge. The paper discusses expressing evidentiality in NA morphologically using the active participle and periphrastically through syntactic relations using the grammaticalized word: gid. $^{2}$

This paper is structured as follows: Section 2 gives a brief background about Najdi Arabic. It also sheds light on some syntactic properties of NA, e.g., word order, subject-verb agreement, NA as being a pro-drop language. In section 3, the concept of evidentiality is discussed. In section 4, evidentiality in Arabic is introduced. In section 5, the main descriptive facts related to the syntactic behaviour of the word gid are introduced. Section 6 investigates the syntactic behaviour of the particle. Section 7 introduces the semantic function of the evidential particle gid. Section 8 concludes the paper.

\section{Objectives and Methodology}

The aim of this paper is to look into the semantics and syntax of the particle GID in NA. Its aim is to respond to the following research questions:

- What is the semantic function of the particle GID in NA?

- What is the base position of the particle GID in NA? And Where does it reside?

The researchers take a descriptive-analytical approach to their analysis. The data used here is a compilation of genuine Najdi Arabic sentences spoken by 25 native speakers. The un/grammaticality of sentences is judged according to the informants' intuition.

\section{Najdi Arabic: A Brief Background}

Najdi Arabic is one of the Gulf dialects spoken in the region of Najd which is located in the middle of Saudi Arabia. Najd refers to the area which spreads from Yemen to the south, to the borders Jordan to the north, and from the oasis Al-Ahsa to the east, to the mountains of Hijaz to the west (Al-Sweel, 1981). The location of Najd region is shaded in red in the map below (from Lewis 2013, p. 3) 3

\footnotetext{
${ }^{1}$ I use the following abbreviations: NA= Najdi Arabic; $\mathrm{EPP}=$ Extended Projection Principle; $\mathrm{TP}=\mathrm{Tense} \mathrm{Phrase} ; \mathrm{VP}=\mathrm{Verb} \mathrm{Phrase} ; \mathrm{FP}=$ Focus Phrase; $\mathrm{T}=$ Tense; $\mathrm{CP}=$ Complementizer Phrase; $\mathrm{SG}=$ Singular; $\mathrm{PL}=\mathrm{Plu}$ (ul; $\mathrm{DEF}=$ the definite article (the); $\mathrm{M}=\mathrm{Masculine}$; $\mathrm{F}=$ Feminine

${ }^{2}$ While gid is sometimes affricated into dzid in Najdi Arabic, the latter is mostly used as an alternative variant by old people, whereas the former is commonly used among youths.

${ }^{3}$ According to Lewis (2013), there are approximately ten million speakers of Najdi Arabic.
} 


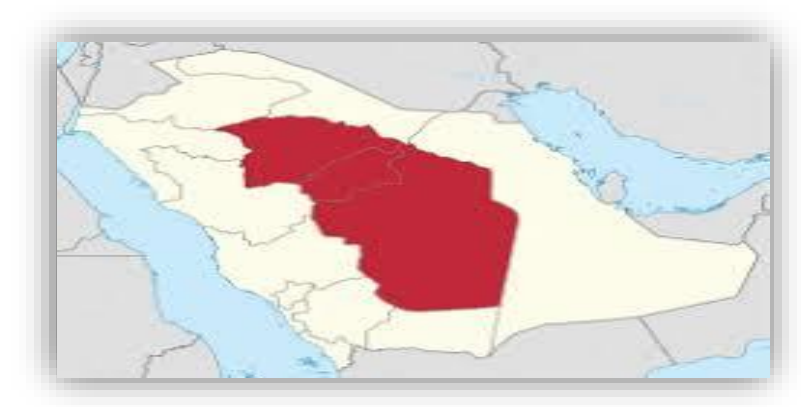

Figure 1: Najd Region of Saudi Arabia

\subsection{Word order in Najdi Arabic}

The word order in NA is flexible. NA can exhibit all possible word orders; SVO, VSO, VOS, OVS, and OSV. Consider the following sentences (1a-e) which show these word orders, respectively. ${ }^{4}$
(1) a. al-wald
Jaaf
DEF-boy
watch.3SG.M.PAST
al-mbaaraat
DEF-match

(SVO)

'The boy watched the match.'

$\begin{array}{lll}\text { b. Jaaf } & \text { al-wald } & \text { al-mbaaraat } \\ \text { watch.3SG.M.PAST } & \text { DEF-boy } & \text { DEF-match }\end{array}$

'The boy watched the match.'
c. Jaaf
al-mbaaraat
al-wald
watch.3SG.M.PAST
DEF-match
DEF-boy

'The boy watched the match.'

$\begin{array}{lll}\text { d. al-mbaaraat } & \text { Jaaf-əh } & \text { al-wald } \\ \text { DEF-match } & \text { watch.3SG.M.PAST-3SG.F } & \text { DEF-boy }\end{array}$

'The boy watched the match.'
e. al-mbaaraat
al-wald
〔aaf-əh
(OSV)
DEF-match
DEF-boy
watch.3SG.M.PAST-3SG.F

'The boy watched the match.'

As we can see from the previous sentences that the word order in NA is free. However, it should be noted that the unmarked (i.e., basic) word order in NA is the SVO, whereas the VSO word order is the marked order (see, e.g., Alshammari, 2018, Alshamari, 2016; Lewis, 2013 for a related discussion). As for the subject-verb agreement, it can be concluded from the examples above (1a-e) that the subject in NA shows full agreement (i.e., person, number and gender) with its subject irrespective of the word order. ${ }^{5}$ Another salient property of NA is that it is a null-copula language. The copula is only overtly expressed in the past tense. See the examples below:

$\begin{array}{ll}\text { (2) a. Ahmad } & \text { mdrris } \\ \text { Ahmad } & \text { teacher }\end{array}$

'Ahmad is a teacher.'
b. Ahmad
kaan
Ahmad
BE.3SG.M.PAST
marris

'Ahmad was a teacher.'

NA is also a pro-drop language. The pronoun/DP subject can be omitted under certain pragmatic circumstances. ${ }^{6}$ Consider the following illustrative examples.
(3) a. (hu)
he
dzaa
come.3SG.M.PAST

'He came.'

$\begin{array}{cl}\text { b. (hii) } & \text { dzat } \\ \text { she } & \text { come.3SG.F.PAST }\end{array}$

'She came.'

c. (ahmad) dzaa

Ahmad come.3SG.M.PAST

\footnotetext{
${ }^{4}$ All the examples in this paper are from NA, unless otherwise indicated.

${ }^{5}$ Modern Standard Arabic (MSA, henceforth) shows asymmetries when it comes to subject-verb agreement. While the verb agrees fully with its subject in the SVO word order, it shows a partial agreement (i.e., only in person and gender) with its subject in the VSO word order. See the following examples from Soltan (2007, p. 34).

$\mathrm{i}$ a. al-Pawlaad-u gar?a-u ad-dars-a (SVO+full agreement) DEF-boys read.3M-PL DEF-lesson-ACC

'The boys read the lesson.'

b. gar?a al-Pawlaad-u ad-dars-a (VSO+partial agreement)

read.3SG.M DEF-boys DEF-lesson-ACC

'The boys read the lesson.'

${ }^{6}$ For more information about NA as a pro-drop language, see Al-Tamimi (2015).
} 
'Ahmad came.'

$\begin{array}{ll}\text { d. (sarah) } & \text { dzet } \\ \text { Sarah } & \text { come.3SG.F.PAST }\end{array}$

'Sarah came.'

\section{Evidentiality: A Review of Related Literature}

Evidentiality is a grammatical category that encodes the source of the information described by the proposition, whether the source of information is the speaker or it is inferred or assumed on the basis of other independent evidence (Plungian, 2001). Aikhenvald (2003) states that "[E]videntiality proper is understood as stating the existence of a source of evidence for some information; that included stating that there is some evidence, and also specifying what type of evidence there is" (p. 1). Functionally, there are different means for expressing evidentiality, one of which has a primary function to express evidentiality, whereas others express non-evidential categories, but conventionally convey evidentiality, e.g., the perfect or the pluperfect (Kehayov, Metslang \& Pajusalu, 2012). Some expressions of evidentiality articulate the evidence implicitly so that it could even be secondary to the expression of degree of reliability (Söderqvist, 2020). Chafe (1986) proposes several sources of knowledge: (i) no source, (ii) evidence, (iii) language and (iv) hypothesis - which he connects to (i) belief, (ii) induction, (iii) hearsay and (iv) deduction.

Typologically, languages vary in encoding evidentiality as well as in selecting the type or types of evidentiality system as we find languages with several evidential distinctions. According to Aikhenvald (2003), there are two types of evidentiality systems: (i) indirective evidential in which the existence of a source for the evidence is stated, but without specifying it; and (ii) languages which specify the type of evidence: visual, inference, or reported (Aikhenvald, 2003, p. 3). In Shipibo-Konibo, the language of the Shipibo, for instance, coding of evidentiality occurs at two different levels: first-hand information and second-hand information. Additionally, specification takes place to indicate either inference or speculation. See the examples below.

(4) Jawen jema-ra ani iki. (Valenzuela, 2003, p. 34)

POss3 village:ABS-DIR.EV large COP

'Her village is large. (I have been there.)'

(5) Jawen jema-ronki ani iki

POSs3 village:ABS-REP large COP

(Valenzuela, 2003, p. 34)

'Her village is large. (I have not been there; I have been told that it is large.)'

In languages like Quechua and Aymara, evidentiality is obligatorily manifested by closed grammatical categories (Aikhenvald, 2004). Central Pomo, one of the seven Pomoan languages spoken in Northern California, for instance, has an evidential mood system to express five different types of evidence a speaker has for his/her proposition (Palmer, 2001)

(6) $\check{c}^{\mathrm{h}} \quad$ éemul-ya

rain fell-VIS

'It rained (I saw it)'

(Palmer, 2001, p. 6)

\subsection{Evidentiality in Arabic}

Even though many languages have found traces of grammaticalization of the category of evidentiality, studies on evidentiality in Arabic are very rare. Aikhenvald (2003) proposes that evidentials may also develop out of participles or other nominalizations. Grammatical categories expressing evedentiality include particles, modals, or even morphemes. Some of these categories, such as conditional mood or perfective aspect, may acquire a secondary evidential-like meaning without directly relating to source of information. Procházka (2018, 2020) indicates that Arabic dialects spoken in Turkey, particularly in Cilicia and the Harran-Urfa region, use active participles to express evidentiality where a speaker refers to second-hand information. He proposes that this change is due to contact with Turkish which obligatorily marks the verbal suffix with $-m i s$ (perfect), whose second function besides evidentiality is to express stativity and perfectively. The latter two functions are expressed by the active participle in many Arabic dialects, including NA. He supposes that the shared stative/perfective functions by both Turkish and Arabic seem to be the starting point which had led to the additional evidential function of Arabic participles. Also, he adds that evidentiality easily spreads through language-contact situations (Aikhenvald, 2004). Below are examples of evidentiality in Arabic dialects spoken in Turkey, taken from Procházka (2020, p. 102).

(7) (Harran-Urfa (Procházka, 2020, p. 102))

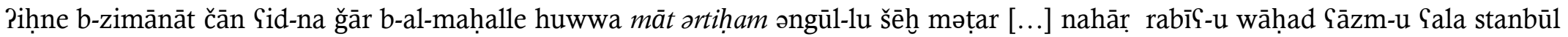
rāyịh maYzūm Yala stanbul māhnio šēh məțar əb-sāgt-u

'Once we had a neighbor in our quarter. He died; he passed away. We called him Sheikh Mətar. One day somebody invited his friend to Istanbul. As he was invited, he went to Istanbul and he took Sheikh Mətar with him.'

(8) Cilicia (Procházka, 2002, p. 201; Procházka, 2018, p. 287)

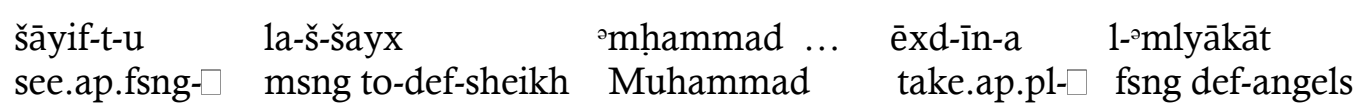

'She saw Sheikh Muhammad, the angels took her.'

The example in (7) shows that the speaker uses perfect forms for events he witnessed himself (mät 'died', artiham 'blessed'), and participles for second-hand information ( $r \bar{a} y i h$ ' 'going', māhiðð 'taking'). In example (8), the active participle éxd-inn-a 'taking' was also used to express a second-hand information of evidentiality.

Besides its use with verbal function of stative/perfective actions, active participle is used in NA to encode evidentiality. One supporting analysis indicating that active participle indexes reportive evidentiality comes from Isaksson (2000, p. 392) examples quoted from Ingham (1986) on Al-Dafïr Bedouin dialect in northern Arabic. Consider the following sentence.

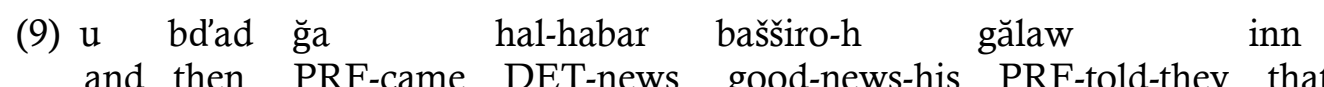




$\begin{array}{llll}\text { Al-Dufìr } & c ́ a ̄ s b-i ̄ n & \text { u } & \text { lā 'alè-ham }{ }^{7} \\ \text { Al- } \underline{D} a f i r & \text { PART-winners } & \text { and } & \text { not } \quad \text { by-them }\end{array}$

'And then the news came to him and they brought him good news that the Al-Dafir had won the battle and that there was nothing wrong with them.'

According to Isaksson (2000), the active participle ćāsb-īn 'PART-winners' in a nominal clause in example (6), giving the news a stative state, expresses reportive evidentiality. Below are examples of active participle that function to encode evidentiality in NA.

$\begin{array}{lll}\text { (10) ahmad } & \text { gaari } & \text { Pal-kitaab } \\ \text { Ahmad } & \text { has read } & \text { DEF-book }\end{array}$

'Ahmad already read the book (I know).'

(11) ahmad Sari sijjaarah

Ahmad has bought car

'Ahmad already bought a car (I know).'

(12) axuuk kaasir ad-dird3

borther. $2^{\text {nd }} \mathrm{SM}$ has broken DEF-drawer

'Your brother has broken the drawer (I know).'

In (10) the active participle gaarj 'has read' indicates that the book was read and the speaker has a second-hand information of evidence on this. Similarly, this applies to sentences (11) and (12). Sometimes, an optional nunation [-in] is suffixed to the active participle, but with no change in meaning. Consider the following sentence.
(13) ahmad
gaari(-jin)
Pal-kitaab
Ahmad
has read
DEF-book

'Ahmad has read the book (I know).'

As noticed in (13) when the nunation [-in] enters into the active participle, the word sometimes gets resyllabified. Nunation in NA corresponds to tanwin in Classical Arabic, which signifies adding a suffix [-un] 'indefinite nominative', [-in] 'indefinite genitive', or [-an] 'indefinite accusative'. However, the function of this suffix has been lost. In NA, it occurs in non-final positions where a noun is followed by a modifying element (Ingham, 1994). ${ }^{8}$ Of note is that the active participle can also have a future reference point when used to signify the future perfect of time/condition clause structures, conveying an intention and/or volition to put the proposed action into practice within the near future (See Ingham, 1994, p. 100-102, for more details).

The active participle functioning to encode evidentiality in NA appears to be similar to evidential discussed by Procházka (2018, 2020) of Arabic dialects spoken in Turkey, particularly in Cilicia and the Harran-Urfa region. Questions on whether this change has spread from Arabic dialects spoken in Turkey to NA and whether such change was originated from language-contact situations with Turkish need further study.

A similar particle to gid used in NA is qad, which is found in Modern Standard Arabic/Classical Arabic, and functions to encode uncertainty of events that are not yet completed, similar to the English modal 'may', if followed by an imperfective verb. With the perfective verb form, however, qad expresses certainty and completeness. Wright $(1967$, p. 286) indicates that "[i]t also serves to mark the position of a past act or event as prior to the present time or to another past act or event, and consequently expresses merely [the English] Perf. or Pluperf.". On the other hand, Dahl and Talmoudi (1979) argue that qad has a pragmatic evidential function (Danks, 2011, p. 161). With $q a d>$ gid, where $q>g$ is not uncommon in NA, and with similar function, i.e., gid expresses a pragmatic evidential function, one may propose that the etymon of gid is qad.

\section{Descriptive facts and preliminary analysis}

In this section, the main descriptive facts related to the syntactic behaviour of the word gid are introduced in addition to providing preliminary analysis to the emerging observations. The major focus is placed on the position of this word as relative to the tense and the main verb in the respective sentence. Surveying the natural examples where this word is used in NA, it is quite clear that the word gid occupies some position which is higher than the main verb. Put it differently, the main verb must follow the word gid, otherwise the respective sentence bears ungrammatical. Consider the following sentences. ${ }^{9}$

$\begin{array}{clll}\text { (14) Pana } & \text { gid } & \text { gareit } & \text { Pal-kitaab } \\ \text { I } & \text { GID } & \text { read.PAST.1SM } & \text { DEF-book }\end{array}$

'I have already read this book.'

(15) * Pana gareit gid Pal-kitaab

I read.PAST.1SM GID DEF-book

Intended: 'I have already read the book.'

In (14) the main verb gareit 'read, past' follows the word gid, hence the sentence is grammatical. On the other hand, in (15), the verb precedes the word gid, thus the sentence is ungrammatical. This restriction on the position of the main verb relative to gid still holds if tense is overtly filled by a tense filler like kaan 'was'. Consider the following sentences.
(16) Pana
gid kint
gareit
Pal-kitaab
I GID was.1S
read.1SM
DEF-book

'I have already read this book.'

$\begin{array}{cllll}\text { (17) *Pana } & \text { gareit } & \text { gid } & \text { kint } & \text { Pal-kitaab } \\ \text { I } & \text { read.1SM } & \text { GID } & \text { was.1S } & \text { DEF-book }\end{array}$

\footnotetext{
${ }^{7}$ I have maintained as much as possible the transcription and gloss of the original text.

${ }^{8}$ See Qafisheh (1997) on nunation of active participle in Gulf Arabic dialects for more details.

${ }^{9} \mathrm{We}$ gloss gid as GID until the point is clear that it is an evidential head.
} 
Intended: 'I have already read the book.'

As a result, one condition for the position of the word gid relative to the verb and tense is possible. This condition is as follows:

(18) The word gid precedes the verb and the tense used in the respective sentence.

This condition is important to pin down where the word gid enters the derivation, as we will explain below in detail. The impossibility of the verb and tense to cross the word gid is a reliable sign that the latter is a head rather than an XP. If the word gid is a phrase, its presence to the left of the verb would not block the verb head movement to an upper head position, following the general lines of the Relativized Minimality (Rizzi ,1990, 2013). The fact that gid blocks the verb movement strongly implies that the two elements belong to the same phrasal status, namely heads. If the word gid is not a head, its presence to the left of verb and to the left of the tense filler does not also block the movement of the latter to a higher position above the functional phrase housing the word gid (as in 19B below). On the other hand, if the word gid is a head, its presence to the left of main verb and to the left of tense filler blocks the movement of the latter to a higher position that is situated above the functional phrase housing the word gid. That is because, for instance, tense filler as a head must first occupy the head position of the functional phrase housing the word gid, and then moves further to a higher position. The word gid functioning as a head blocks this potential movement given that the functional phrase housing the word gid is filled by gid per se (as in 19A below). Consider the following schematic presentations.

A.

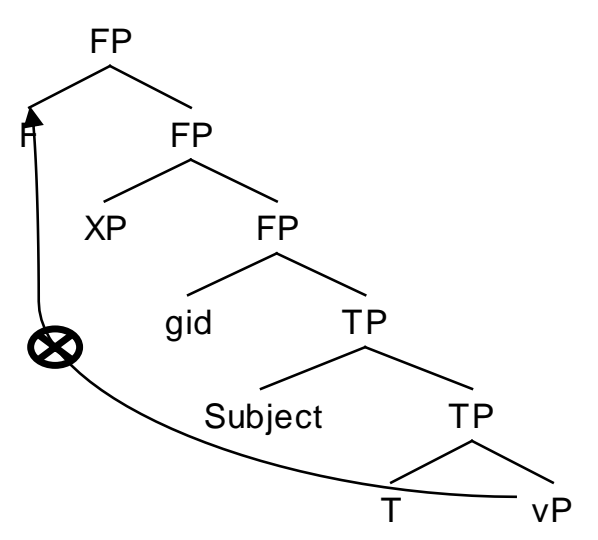

B.

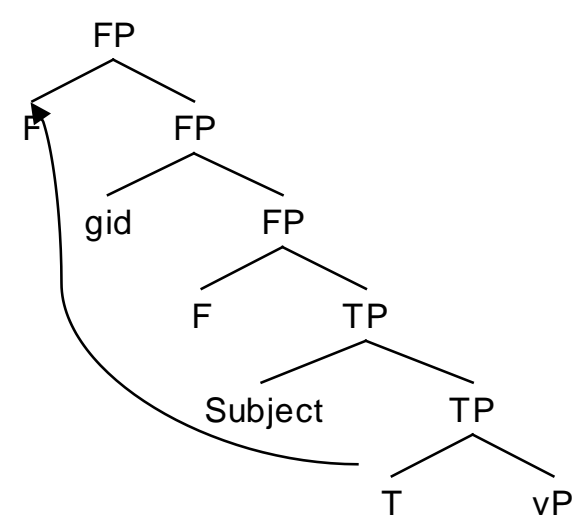

The restriction that tenses filler and the main verb must appear to the right of gid without any possibility for crossing over gid is strong evidence for the headedness of gid (cf. Matushansky, 2006, among others).

What is worth investigating at this point is the obvious observation that gid subcategorizes for a verbal complement with past tense interpretation. In other words, the complement of the word gid must be a verb in past tense. If a verb appearing to the right of gid is in its present tense, the sentence becomes ungrammatical. Consider the following sentence.
(20) *?ana
gid agra
?al-kitaab
I GID read.PRES.1SM
DEF-book

Intended: 'I am reading the book.'

The ungrammaticality of the sentence in (20) remains even if the verb is in future tense, i.e., preceded by the future auxiliary rah 'will'.

(21) * Pana gid rah Pagra

IGID will read.PRES.1SM
Intended: 'I will read the book.'

DEF-book

Pal-kitaab

Accordingly, it can be concluded that the word gid is only licensed when it is followed by a past tense verb. The fact that gid is not followed by an imperfective verb indicates that verb following gid is not in its thematic position, heading the VP. Following Benmamoun (2000) and Aoun, Benmamoun and Choueiri (2009), we argue that the past tense of the verb is derived through verb movement to Tense. Consider the following schematic representation of how the past tense of the verb is derived.

(22)

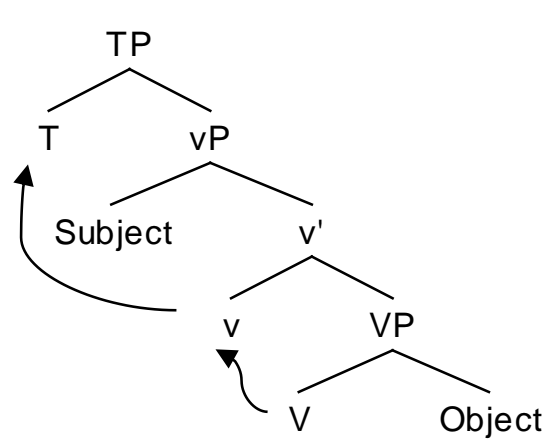

Along the line of this analysis, the word gid is followed by TP rather than vP/VP. This claim can be corroborated when sentences with overt tense are taken into account. As we hinted to above, gid can be followed by the tense filler, kaan 'was' and the sentence holds grammatical. Consider the sentences in (23) and (24).

$\begin{array}{cllll}\text { (23) Pana } & \text { gid } & \text { kint } & \text { gareit } & \text { Pal-kitaab } \\ \text { I } & \text { GID } & \text { was.1S } & \text { read.1SM } & \text { DEF-book }\end{array}$

'I have already read this book.'
(24) * Pana kint
gid
gareit DEF-book
Pal-kitaab

'Intended: I have already read this book.'

This being the case, it can be safely argued now that the maximal projection headed by gid is situated above TP; otherwise, the fact that gid is followed by a past tense is hard to account for within the recent generative theorizing that bans downward movement (Chomsky, 1993, $1995,2005)$. So, the direct and simple proposal is that the functional layer headed by gid is situated directly above TP in the respective 
clause. This proposal accounts for the sub-categorizational properties of gid in that the complement follows the head not the other way round.

\subsection{Syntactic analysis of gid: gid as a head phrase}

Let us investigate the first question (why does the subject appear to the left of gid although it is expected to be in the Spec position of TP?) Drawing on our account that the functional phrase headed by gid c-commands TP, it is expected that the subject appears to the right of gid, which is contrary to fact. Consider the following examples.
(25) Pana$$
\text { gid gareit }
$$$$
\text { AUX read.PAST.1SM }
$$
Pal-kitaab
DEF-book

'I have already read the book.'

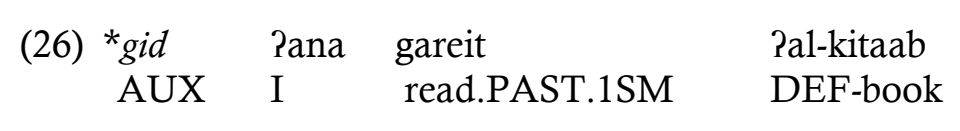

Intended: 'I have already read the book.'

Subject must be to the left of gid. For this, we argue that gid as a head has an EPP feature within its featural make-up. It is the EPP feature on gid that forces the subject to vacate Spec, TP in declarative sentences to move to Spec, FP which is headed by gid. Along these lines, it can be postulated that the subject moves out of its thematic position to Spec, TP satisfying the EPP feature on T. Then, it moves to Spec, FP headed by gid, as schematized in the following structure (the subject movement is boldfaced).

(27)

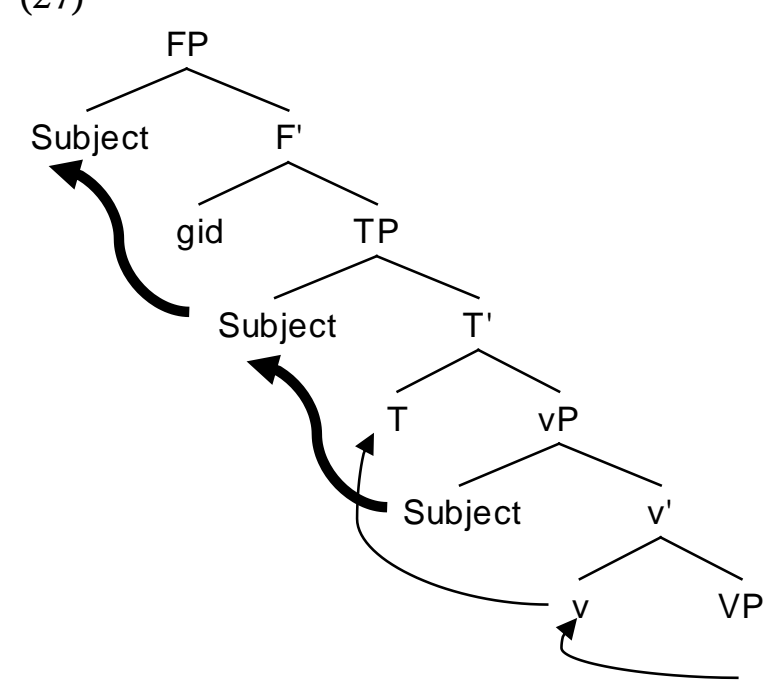

In this way, the obligatory position of the subject in declarative sentences to the left of gid is explained. One might ask here a question of how the EPP feature of gid is satisfied in cases where there is no overt subject, given the null-subject status of the NA. Consider the following sentences.

$\begin{array}{lll}\text { (28) gid } & \text { gareit } & \text { Pal-kitaab } \\ \text { GID } & \text { read.PAST.1SM } & \text { DEF-book }\end{array}$

'I have already read the book.'

(29) gid gara Pal-kitaab

$\begin{array}{lll}\text { GID } & \text { read.PAST.3SM } & \text { DEF-book }\end{array}$

'He has already read the book.'

$\begin{array}{ll}\text { (30) gid } & \text { garat } \\ \text { GID } & \text { read.PAST.3SfDEF-book }\end{array}$

'She has already read the book.'

In sentences in (28) through (30), there is no over subject to the left of gid, but all sentences remain grammatical though. For such cases, we follow the widely-held assumption for Arabic sentence that in sentences with no overt subject, the subject position is filled by null pro whose identity is detected through the inflections appearing on the verb (see, for example Fassi Fehri, 1993, Al-Aqarbeh, 2011; Versteegh, 2014 in this regard). It is clear from the examples in (28) through (30) that the verb has different inflectional forms, depending on the identity of the hidden subject. In such cases, we argue that Spec, FP headed by gid is occupied by pro which is base-generated in Spec, VP in cases of transitive sentences or in Spec, VP in cases on intransitive sentences. Then this pro, analogous to cases with overt subject, moves to Spec, TP, then to Spec FP headed by gid. ${ }^{10}$ As such, the EPP feature on gid is satisfied by pro. What is important to note at this point is that the null pro can move from its thematic position to higher positions. The null pro thus can meet the EPP features on T and gid alike, and hence there is no need to deploy a different strategy to meet the EPP features on T or gid.

As for the second question (why must the verb following gid be in past tense?), we argue that the word gid as a head has an uninterpretable PAST feature in its featural make-up. Given Chomsky's assumptions (1995) on that uninterpretable feature must be deleted before handing the derivation over to the LF components, we argue that the word gid enters syntactic operation with tense to value this feature. Before elaborating on this claim, consider the Principle of Full interpretation (FI):

The principle FI is assumed as a matter of course in phonology; if a symbol in a representation has no sensorimotor interpretation, the representation does not qualify as a PF representation. This is what we called the "interface condition". The same condition applied to LF also entails that every element of the representation have [sic) a (language independent) interpretation (Chomsky, 1995, p. 27).

This principle was reformulated as the interpretability condition which states the following:

\footnotetext{
${ }^{10}$ We still argue following the mainstream assumptions held for the Arabic sentence (cf. Aoun et al 2010, Fassi Fehri 2012) that Spec, TP must be projected due to the EPP feature on T. Whether this assumption is valid or not lies beyond the scope of this paper.
} 
The Interpretability Condition: LIs [lexical items 1 have no features other than those interpretable at the interface, the properties of sound and meaning. (Chomsky, 2000, p. 113)

The condition in (29) indicates that the lexical items do not have any uninterpretable features at the interface levels; if there are some features, they have to be deleted. Only the features that have semantic and phonological contents are permitted to reach the interface levels. The question now is how the uninterpretable PAST feature on the word gid is deleted. We here make recourse to the Agree operation to account for the deletion of this feature. Chomsky (2001) argued for certain conditions on the Agree relation between the searching probe and the matching goal (2001, p. 122). These conditions are as follows:

(33)
The probe $\boldsymbol{\alpha}$ agrees with the goal $ß$ provided that:
a- $\boldsymbol{\alpha}$ has uninterpretable $\varphi$-features.
b- $ß$ has matching (un)interpretable $\varphi$ features.
$c-\beta$ is active by virtue of having an unvalued Case feature.
d- $\boldsymbol{\alpha}$ c-commands $ß$.
e- There is no potential goal $\Upsilon$ intervening between $\boldsymbol{\alpha}$ and $B$.

Given that the word gid has PAST feature which is uninterpretable, the claim is that the word gid is an active probe. It starts looking for its domain for an active goal that has a matching PAST feature which must be interpretable. Let us first focus on the cases where the verb is in the past tense as in (25) which is repeated below as (34) for convenience.

$\begin{array}{clll}\text { (34) Pana } & \text { gid } & \text { gareit } & \text { Pal-kitaab } \\ \text { I } & \text { GID } & \text { read.PAST.1SM } & \text { DEF-book }\end{array}$

'I have already read the book'.

We argue that the word gid finds the verb adjoining the tense (cf. Benmamoun, 2000; Aoun et al, 2010). The verb is endowed with an interpretable matching PAST feature. Consequently, an Agree relation is established between the word gid and the verb, while the latter is in the past tense. This relation results in deleting the uninterpretable matching PAST feature on the word gid.

On the other hand, in cases where the verb is in the present tense or the imperfective form (as in the sentences in (20) and (21) above repeated below as (35)), there is no Agree relation established between gid and the verb given that the latter does not have a matching interpretable $[\mathrm{PAST}]$ feature. This leads to the ungrammaticality of the respective sentence.
(35) * Pana gid agra
IGID read.PRES.1SM
Pal-kitaab

Intended: 'I am reading the book.'
(36) * Pana gid rah Pagra
IGID will read.PRES.1SM
Pal-kitaab
DEF-book

Intended: 'I will read the book.'

At this point, one might ask a question: why the word gid does not inflect for agreement. Consider the following sentences.
(37) * gid-i
gareit
GID-1S read.PAST.1SM
Pal-kitaab
DEF-book

Intended: 'I have already read the book.
(38) * gid-uh
gara
read PAST 3SM
Pal-kitaab
DEF-book

Intended: 'He has already read the book.
(39) * gid-ha
GID-3SF
garat Pal-kitaab
read.PAST.3SfDEF-book

Intended: 'She has already read the book.

For this, we claim that the word gid does not have $\varphi$-features in its featural bundle, hence the lack of any overt agreement between gid and any other element including subject.

\subsection{Semantic function of gid: gid as an evidential particle}

The last issue meriting consideration is related to the semantic function of gid. We claim that gid is an evidential particle in the sense that it denotes higher degrees of evidentiality. It is only used when a speaker is certain on the content of his/her utterance. Evidence for this contention can be adduced from the fact that the word gid cannot co-occur with any adverb that expresses probability or lesser degrees of evidentiality. Consider the following sentences.
(40) * gid
Pihtimaal
gara
Pal-kitaab
EVD probability read.PAST.3SM
DEF-book

Intended: 'It is probable that he has already read the book.

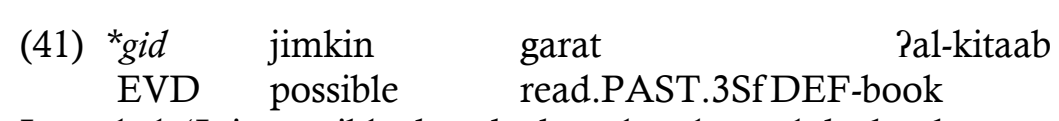

Intended: 'It is possible that she has already read the book.

Accordingly, it can be postulated that gid is a head that projects an evdientaility projection between $\mathrm{CP}$ and $\mathrm{TP}$. 


\section{Results and Discussion}

This work explores the word gid in NA utilizing the recent assumptions of the minimalist program (Chomsky, 1993, 1995, 2000, 2001, and 2005). gid is an evidential head that instantiates its own projection situated between CP and TP. In order to account for the fact that the subject must precede this word in declarative sentences, we argue that gid has an EPP feature, hence the specifier position of the evidentiality Phrase headed by gid is filled by a subject. In order to account for why gid subcategorizes for past verbs, we argue that gid has [PAST] feature which is uninterpretable and hence must be deleted before the derivation is handed over to the LF. We postulate that the deletion of [PAST] feature is conducted through an agree operation that is established between gid and the verb. On the other hand, gid does not have $\varphi$-features in its featural bundle, hence the lack of any overt agreement between gid and any other element including subject. We also discuss the semantic function of gid and claim that this word is an evidentiality particle in the sense that it denotes higher degrees of evidentiality.

\section{Bio-Note}

Ahmad Alshammari is an assistant professor of linguistics at the University of Ha'il. He obtained his PhD in linguistics from the University of Newcastle upon Tyne, UK. His main interests are syntactic theory in general, especially the syntax of the left periphery of clauses in Arabic.

Wafi Alshammari is an assistant professor of linguistics at the University of Ha'il. He obtained his PhD in linguistics from Indiana University-Bloomington, USA. His main interests are sociolinguistics, language contact, and Arabic pidgins and creoles.

\section{References}

Aikhenvald, A. I. (2003). Evidentiality in typological perspective. In Alexandra Aikhenvald and R M Dixon (eds.), Studies in Evidentiality, (pp. 1-32). Philadelphia: John Benjamins Publishing Company.

Aikhenvald, A. (2004). Evidentiality. Oxford: Oxford University Press.

Alhaisoni, E., Jarrah, M. A., \& Shehadeh, M. S. (2012). An investigation of evidentiality in the Arabic language. International Journal of Linguistics, 4(2), pp.260-273.

Al-Aqarbeh, R. N. (2011). Finiteness in Jordanian Arabic: a semantic and morphosyntactic approach. (Doctoral dissertation, University of Kansas).

Alshamari, M. R., \& Jarrah, M. (2016). A Minimalist-Based Approach to Phrasal Verb Movement in North Hail Arabic. International Journal of English Linguistics, 6(1), p.24.

Alshammari, A. R. (2016). The Negative Polarity Item umur in Najdi Arabic. Studies in Literature and Language, 11(4), pp.1-8.

Alshammari, A. R. H. (2018). The syntax of temporal and conditional adverbial clauses in Najdi Arabic (Doctoral dissertation, Newcastle University).

Al-Sweel, A. (1981). The verbal system of Najdi Arabic: A morphological and phonological study. MA Dissertation. University of Washington.

Al-Tamimi, M. (2015). Arabic pro-drop. M.A. Thesis. Eastern Michigan University.

Aoun, J. E., Benmamoun, E. \& Choueiri, L. (2009). The syntax of Arabic. Cambridge University Press.

Benmamoun, E. (2000). The feature structure of functional categories: A comparative study of Arabic dialects (Vol. 16). Oxford University Press on Demand.

Brinton, L. J. (1996). Pragmatic markers in English: Grammaticalization and discourse functions (Vol. 19). Walter de Gruyter.

Chafe, W. (1986). Evidentiality in English conversation and academic writing. In Walance L. Chafe and Johanna Nichols (eds.), Evidentiality: The linguistic coding of epistemology, (pp. 261-272). Norwood NJ: Ablex.

Chomsky, N. (1993). A minimalist program for linguistic theory. The view from Building 20: Essays in linguistics in honor of Sylvain Bromberger, ed. by Kenneth Hale and Samuel Jay Keyser, 1-52.

Chomsky, N. (1995). The minimalist program (Vol. 28). Cambridge, MA: MIT press.

Chomsky, N. (2000). Minimalist Inquiries: The Framework. In Lasnik, H., R. Martin, D. Michaels \& J. Uriagereka (eds.) Step by step.' essays on minimalist syntax in honor of Howard Lasnik. Cambridge. Mass: MIT Press.

Chomsky, N. (2001). Derivation by phase. In Kenstowicz, M. (ed.) Ken Hale. A Life in Language. Cambridge, Mass: MIT Press. 1-52.

Chomsky, N. (2005). Three factors in language design. Linguistic inquiry, 36(1), pp.1-22.

Dahl, O., \& Talmoudi, F. (1979, April). Qad and laqad: tense/aspect and pragmatics in Arabic. In Aspectology Workshop at the Fifth Scandinavian Conference of Linguistics (pp. 51-68).

Danks, W. (2011). The Arabic verb: Form and meaning in the vowel-lengthening patterns. Amsterdam: John Benjamins Publishing Company.

DeLancey, S. (2004). Grammaticalization from syntax to morphology. An International Handbook on Inflection and Wordformation, 17, pp.1590-1599.

Fehri, A. F. (1993). Temporal, Aspectual, and Modal Categories. In Issues in the Structure of Arabic Clauses and Words (pp. 141-212). Springer, Dordrecht.

Fehri, A. F. (2012). Key features and parameters in Arabic grammar (Vol. 182). John Benjamins Publishing.

Heine, B. (2006). Possession: Cognitive sources, forces, and grammaticalization (Vol. 83). Cambridge University Press.

Hopper, P. J., \& Traugott, E. C. (2003). Grammaticalization. Cambridge University Press.

Ingham, B. (1986). Notes on the dialect of the Ā1 Murra of eastern and southern Arabia. Bulletin of the School of Oriental and African Studies, University of London, 271-291. 
Ingham, B. (1994). Najdi Arabic: Central Arabian (Vol. 1). John Benjamins Publishing.

Isaksson, B. (2000). Expressions of evidentiality in Hebrew and Arabic. In Lars Johanson and Bo Utas, Evidentials: Turkic, Iranian, and neighbouring languages, (pp. 383-400). Berlin: Mouton de Gruyter.

Kehayov, P., Metslang, H., \& Pajusalu, K. (2012). Evidentiality in Livonian. Linguistica Uralica XLVIII 1, $41-54$.

Lewis, R. (2013). Complementizer Agreement in Najdi Arabic. M.A. Dissertation, University of Kansas.

Matushansky, O. (2006). Head movement in linguistic theory. Linguistic inquiry, 37(1), pp.69-109.

Palmer, F. (2001). Mood and Modality, $2^{\text {nd }}$ ed. Cambridge: CUP.

Plungian, V. (2001). The place of evidentiality within the Universal grammatical space. Journal of Pragmatics 33, $349-357$.

Procházka, S. (2002). Die arabischen Dialekte der Cukurova (Südtürkei). Wiesbaden: Harrassowitz.

Procházka, S. (2018). The northern fertile crescent. In Clive Holes (ed.), Arabic Historical Dialectology: Linguistic and Sociolinguistic Approaches, (pp. 257-292). Oxford: Oxford University Press.

Procházka, S. (2020). Arabic in Iraq, Syria, and southern Turkey. In Christopher Lucas and Stefano Manfredi (eds.), Arabic and Contact-induced Change, (pp. 83-114). Berlin: Language Science Press.

Rizzi, L. (1990). Relativized minimality. The MIT Press.

Rizzi, L. (1997). The fine structure of the left periphery. In Elements of grammar (pp. 281-337). Springer Netherlands.

Rizzi, L. (2013). Locality. Lingua, 130, pp.169-186.

Söderqvist, E. (2020). Evidential marking in spoken English: Linguistic functions and gender variation. PhD Dissertation. Uppsala Universitet, Sweden.

Soltan, U. (2007). On Formal Feature Licensing in Minimalism: Aspects of Standard Arabic Morphosyntax. Ph.D. thesis, The University of Maryland. College Park.

Thepkanjana, K., \& Ruangmanee, S. (2015). Grammaticalization of the verb 'to acquire'into modality: a case study in Vietnamese. Taiwan Journal of Linguistics, 13(2), 117-150.

Trousdale, G. (2008). Words and constructions in grammaticalization: The end of the English impersonal construction. Studies in the history of the English language IV: Empirical and analytical advances in the study of English language change, 301-326.

Valenzuela, P. M. (2003). Evidentiality in Shipibo-Konibo, with a comparative overview of the category in Panoan. Typological Studies in Language, 54, 33-62.

Versteegh, K. (2014). Arabic language. Edinburgh University Press.

Wright, W. (1967). A Grammar of the Arabic Language, Vol. 2, London: Cambridge University Press. 